westerly wind in northern Egypt at the 4000 metre level, in spite of the dominance of northerly winds from 500 metres to 2000 metres. The resultant at 4000 metres height is not far from due west in any month, and on an average for the whole year must be almost exactly from west.

At Khartoum conditions aloft are complicated by the complete seasonal change occasioned by the northward and southward movements of the equatorial wind circulations in accordance with the varying declination of the sun. In the rainy season the resultant has an easterly component from 3000 to 5000 metres, and is on an average nearly due east between 4000 metres and 5000 metres from July to September. Shaw's "Manual " does not give the mean pressure distribution at 4000 metres in July for the northern hemisphere, so a similar comparison cannot be made for that level. There is, however, a diagram for 8000 metres. If the latter is correct, one would expect light northerly winds to predominate above the easterlies found by Sutton. It is possible that these exist, but it may be noted that Sutton's resultant direction for July backs from nearly north-east to a little south of east, on passing from 4000 metres to 5000 metres, and it appears more probable that the diagram in question (Fig. 167, p. 162 of vol. 2) requires slight modification in view of Sutton's statistics.

In the dry season at Khartoum it appears that westerly or north-westerly winds prevail at about 3000 to 4000 metres, not winds from between west and south-west, as is implied by the figurs in Shaw's "Manual" referred to earlier in this notice, which gives the pressure distribution at 4000 metres in January. It may be noted that Teisserenc de Bort is the authority on which Shaw based his diagrams. It is to be hoped that someone will be willing presently to revise our notions of mean air movement at 4000 metres and 8000 metres over Africa in the light of such valuable papers as this, when more of the younger meteorological services have carried on systematic soundings for a long series of years.

\title{
Drift Bottle Experiments in the Gulf of Mannar.
}

$\mathrm{M}^{\mathrm{R}}$ R. A. H. MALPAS, in his work entitled "Preliminary Account of the Results of Drift Bottle Experiments in the Gulf of Mannar" (Ceylon Journal of Science--Section C, Fisheries : Bulletin of the Ceylon Fisheries, vol. 4, April 1930), describes the continuation of the experiments initiated by Mr. James Hornell in 1907. The recent researches have been on a much larger scale, drift bottles being liberated, so far as was practicable, throughout the year from 1913 until 1927 (except for the years 1917-19) and the area extended to include the whole of the portion of the Gulf above the Colombo-Tuticorin line, in order to obtain some idea of the monthly current changes.

In the Gulf of Mannar there is a more or less regular cyclic movement of water controlled by the northeast and south-west monsoons. The effect of the south-west monsoon, which has its maximum in JulyAugust, is to force oceanic water of high salinity and low temperature into the Gulf, whilst with the northeast monsoon with its maximum in DecemberJanuary the surface water is replaced by water of a low salinity. The oceanic current operates chiefly in the southern portion of the Gulf and rarely penetrates so far north as the pearl banks. There is, however, a definite surface drift over the pearl banks area due to the wind, and the banks lack protection from the violence of the south-west monsoon. which at its height makes the waters at the bottom turbid and may cause silting.

Under favourable conditions of south-west monsoon and current in July and August, the pelagic larvæ liberated at Tuticorin might reach Ceylon and settle as spat, and, conversely, Tuticorin might receive spat from Ceylon in December and January during the north-east monsoon.

In analysing the drift for each month of the year, the direction of drift of each bottle recovered is assumed to be from the point of liberation to the point of recovery, and naturally no allowance is made for the various possible changes in direction of drift between liberation and recovery.

The number of recovered bottles during the period of the north-east monsoon was small and these indicate no marked currents in the Gulf opposed to the prevailing north-east winds which would carry the bottles to either the Indian or Ceylon coasts. Many were probably earried out into the ocean and so lost. The period from March to April is transitional between the two monsoons with an average of south-west winds, the returns indicating a change of drift from south-west to north-north-east. In the pearl banks area and up the Ceylon coast the current was northerly with a slight westerly tendency. The "little monsoon" sets in at the end of April with wind and rain and a pronounced north-east drift. The south-west monsoon from May to October opens with a burst of rain and wind about the middle of May, through June gradually becoming stronger until its full force is reached towards the end of July and beginning of August, then weakens and dies away in October: average wind south-west in May-July, more westerly in AugustOctober. The bottle returns indicate north to north east drift, becoming more easterly as we proceed northwest across the Gulf.

On the whole, the results of the bottle returns are in agreement with the Admiralty interpretations.

\section{British Archæology.}

$A$ MONG the numerous papers on British archæology $A$ read before Section $H$ (Anthropology) of the British Association at the recent Bristol meeting, two are of special interest. (1) Mr. C. W. Phillips, in discussing "Earthworks on Walton Common Down, near Clevedon ", pointed out the great importance of air photography. On Walton Common Down, 250 feet above sea-level, is a group of earthworks in the form of a roughly circular enclosure 340 feet in diameter, with an entrance on the south-south-west side. An avenue formed by banks of similar construction projects from it 100 yards to the north-east and ends in a cross bank. A disc barrow stands to the north of the avenue and a partially destroyed rhomboidal earthwork to the south.

Until the site had been examined from the air, it was considered that the circle and avenue might be the remains of an ancient sacred place, but air photography proved a wholesome corrective by showing that outlying portions of one of the groups of Celtic fields underlie the earthworks, which are thus subsequent in date. Both air photography and field work show intensive remains of Celtic eultivation on the Common Down, associated with two groups of proved hut circles. It is suggested that the cross bank and avenue might have been devices for marshal. 
ling and sorting sheep, similar works in Ireland being known to be thus associated.

(2) Mrs. E. M. Clifford's paper on prehistoric discoveries at Barnwood, Gloucester, opened up possibilities of decisive evidence as to the physical type of the native British who were living in the district when the Roman legions reached Gloucester (Glevum). The site lies by the side of the Roman road leading from Gloucester to Cirencester, It is an extensive flat field two miles distant from the Severn and 80 feet above the level of that river. The field has been excavated to a depth of 8 feet by the Gloucester Stone Company, and the discoveries reported by Mrs. Clifford were made during operations.

A section shows an upper foot of soil, then 2-3 feet of brick-earth, then bedded gravels, upper and lower. The lower gravels are rich in remains of mid-Pleistocene fauna; in the gravels and brick-earths have been found Acheulean, Mousterian, and Aurignacian stone implements. No human remains of Pleistocene date have been discovered as yet, but burials of a later date- of the early bronze age period (a beaker burial), of La Tène II.-and an extensive Roman cemetery (first and second century A.D.) have been carefully examined. In the Roman cemetery more than 100 inhumations and 50 cremations have been studied.

Sir Arthur Keith visited the site after the British Association meetings and considers it to be of great historical importance. He thinks that the evidence points to the people buried in the cemetery as being native British, thus giving a complete picture of the kind of people who lived in the west of Britain when the Romans reached Glevum. Mrs. Clifford acknowledged expert assistance received from Sir Arthur Keith, Mr. J. W. Gray, Prof. L. S. Palmer, the late Dr. C. W. Andrews, and Mr. Reginald A. Smith.

\section{'Serialism.'}

THE work entitled "An Experiment with Time", 1 published in 1927, in which numerous remarkable instances were given of dreams that had occurred prior to the occurrence of the events corresponding to them in waking experience, will be familiar to many readers of NATURE. In order to account for these phenomena, the author of the book, Mr. J. W. Dunne, propounded in it a theory, which he designated 'serialism'; and he has recently been giving broadeast talks in further elucidation of his theory.

Mr. Dunne maintains that, so far from being a fallacy, an infinite regress is traceable not only in the nature of physical existence but also in the nature of our awareness of the physical world. The physical world is, he argues, so constituted that it can be viewed as a series of more and more fundamental worlds ; and can, in fact, be understood only when examination of it is carried so far as the second term of the series. The process of scientific investigation consists, he urges, essentially of two steps-the search for the truly " given ', or compulsory, elements in our knowledge, and the description of such given knowledge as knowledge of an existing world. The awareness that some of our knowledge is compulsory is itself second-term knowledge. Thus, knowledge of a real external world and knowledge of the self are correlative-both are given in willed activity, primarily the activity of attention. The ultimate will and the ultimate physical entity that is the opposite of will belong to the realm of indefinable "being', from which the defined fields of physical and psychical existence are to be extracted.

The second-term field of physics exhibits entities of a plainly regressive character; moreover, it does not constitute a closed physical system, but discloses gaps in its continuity, and these gaps indicate where there may be voluntary intervention. If the physical world be described in terms of matter, the regress comes to light when matter is derived from a submatter, called space, and this again from a sub-space, and so on.

The most striking confirmation of the theory is, however, afforded, Mr. Dunne thinks, by an analysis of the time regress. If we say of an event that it is happening 'now', we are adding something to the simple notion of a time-order ; and the 'now-mark', which characterises the first-term field of physical existence, must itself travel. When, in the series of events $A B C, B$ is now and later $C$ is now, they are earlier and later in a more fundamental time, in which all that is past and future in the lesser time coexists. In modern physics the importance of the 'now-mark' has, it is contended, become readily apparent; for the probable structure of $B$ depends very largely upon $B$ 's position with regard to a 'now'. Many paths which a particle may take when $A$ is 'now' are no longer open when $C$ has become 'now'.

\section{University and Educational Intelligence.}

Cambridge.-The Adam Smith Prize has been awarded to Miss R. L. Cohen, of Newnham College, for an essay entitled "Factors affecting the Price of Potatoes in Great Britain".

At St. John's College the following have been elected into fellowships : W. D. V. Hodge, Wrangler with distinction, Part II. Mathematical Tripos 1925 , Smith's Prize 1927; J. G. Semple, Wrangler with distinction, Part II. Mathematical Tripos 1927, Ray. leigh Prize 1929 ; P. E. Vernon, Natural Sciences Tripos Part I., 1926, Class 1, Moral Sciences Tripos Part II., 1927, Class 1, Rockefeller Foundation Fellowship in Social Sciences at Yale University 1929.

The Henry Sidgwick Memorial Lecture at Newnham College will be given by Prof. A. V. Hill, professor of physiology in the University of London, on Saturday, Nov. 22, at 5 P.M. The title of the lecture is "Biology in Education".

LEEDS.--Under the will of the late Lord Brotherton, who died on Oct. 21 last, the University is to receive $£ 100,000$ for general purposes. This benefaction will be additional to the gift of the University Library, his collection of books, and an endowment for upkeep.

OXFORD.-At the meeting of Congregation on Nov. 4, a decree was passed providing that $£ 2000$ of an anonymous gift to the University of $£ 5000$ should be invested and the income used for the purchase of scientific books and periodicals. Another decree was passed giving power to the Vice-Chancellor to make provision for carrying on the duties of the Savilian professorship of astronomy during the vacancy caused by the death of Prof. H. H. Turner.

Trie Prince of Wales has consented to become president of the fourth Congress of Universities of the Empire to be held in Edinburgh next summer, and, circumstances permitting, to welcome and address the delegates and representatives in London on July 3.

Prof. L. M. Dennis, of the Department of Chemistry, Cornell University, informs us that the following have accepted appointment to the George Fisher Baker Non-Resident Lectureship in Chemistry at Comell University for the next two years : first term, 1930 1931, Prof. G. Hevesy, Freiburg in Breisgau; second

No. 3185. VoL. 126$]$ 